UDC 551.35+911.3:504.052

Daria Olegivna Pankratenkova,

Senior Lecturer, Department of Physical Geography and Environmental Sciences,

I. I. Mechnikov Odessa National University, 2 Shampanskiy Per., Odessa, 65058, Ukraine, e-mail: dashap15041989@gmail.com, https://orcid.org/0000-0002-9888-7281

\title{
CONSTRUCTIVE-GEOGRAPHIC FOUNDATIONS OF NATURE MANAGEMENT ON THE NORTH-WESTERN COAST OF THE BLACK SEA
}

Д. О. Панкратенкова. КОНСТРУКТИВНО-ГЕОГРАФІЧНІ ОСНОВИ УПРАВЛІННЯ ПРИРОДОКОРИСТУВАННЯМ НА УЗБЕРЕЖЖІ ПІВНІЧНО-ЗАХІДНОЇ ЧАСТИНИ ЧОРНОГО МОРЯ. Статтю присвячено проблемі управління природокористуванням на узбережжі північно-західній частині Чорного моря, щзо виникла на основі нерачіонального використання природних ресурсів. Розглянуто види антропогенного впливу і господарської діяльності (зростання населення в прибережних районах, урбанізачія, забруднення вод акваторії, рекреація, рибальство, будівництво берегозахисних, портових, гідротехнічних та інших видів споруд, промисловість, сільське господарство і т.д.), щчо призводять до розвитку деструктивних процесів та деградації морських берегів.

На основі аналізу існуючої законодавчої системи управління в Украӥні, розкрито основні причини хаотичного освоєння морського узбережжя Чорного моря. Проаналізовано діяльність прийнятої всесвітньою громадськістю та ООН концепціі «Комплексного управління береговою зоною» (КУБЗ) в різних країнах світу. Головною метою концепиії є розробка проектів природокористування на узбережжях, що забезпечують оптимальний баланс між природними системами та соціальноекономічним розвитком. Висвітлено изілі, засади та принципи впровадження КУБЗ в Україні, яке передбачає тісну взаємодію наукової, сочіально-економічної та законодавчої сфер. Встановлено, щзо для розробки будь-яких проектів в береговій зоні моря, необхідно мати наукове природне обтрунтування.

Розроблені та вдосконалені конструктивно-географічні основи управління природокористуванням є універсальними й мають важливе значення для гармонізачії взаємовідносин між людством і природою, шляхом зниження антропогенних навантажень не тільки в межах берегової зони північно-західної частини Чорного моря, але й Причорноморських краӥн $i$ всього Світового океану в цілому. Викладені положення можуть стати основою законодавчих природоохоронних проектів.

Ключові слова: природокористування, антропогенний вплив, принципи, комплексне управління береговою зоною (КУБЗ), берегова зона, північно-західна частина, Чорне море, Украӥна.

Д. О. ПанКратенкова. КОНСТРУКТИВНО-ГЕОГРАФИЧЕСКИЕ ОСНОВЫ УПРАВЛЕНИЯ ПРИРОДОПОЛЬЗОВАНИЕМ НА ПОБЕРЕЖЬЕ СЕВЕРО-ЗАПАДНОЙ ЧАСТИ ЧЕРНОГО МОРЯ. Статья посвящена проблеме управления природопользованием на побережье северо-западной части Черного моря, возникщей на почве нерачионального использования природных ресурсов. Рассмотрены основные виды антропогенного влияния и хозяйственной деятельности (рост населения в прибрежных районах, урбанизачия, загрязнение вод акватории, рекреаиия, рыболовство, строительство берегоза шитныхх, портовых, гидротехнических и других видов сооружений, промышиленность, сельское хозяйство и т.д.), что приводят к развитию деструктивных процессов и деградации морских берегов.

На основе анализа существующей законодательной системы управления в Украине, раскрыты основные причины хаотического освоения морского побережья Черного моря. Проанализировано деятельность принятой всемирной общественностью и ООН кониепиии «Комплексного управления береговой зоной» (КУБЗ) в разных странах мира. Главной иелью концепции является разработка проектов природопользования на побережьях, обеспечивающих оптимальный баланс между природными системами и социально-экономическим развитием. Высветлено иели, основы и принципы внедрения КУБЗ 6 Украине, которое предусматривает тесное взаимодействие научной, сочиально-экономической и законодательной сфер. Установлено, что для разработки любых проектов в береговой зоне моря, необходимо иметь научное природное обоснование.

Разработанные и усовершенствованные конструктивно-географические основы управления природопользованием являются универсальными и имеют важное значения для гармонизации взаимоотношений между человечеством и природой, путем снижения антропогенных нагрузок не только в пределах береговой зоны северо-западной части Черного моря, но и Причерноморских стран и всего Мирового океана в ичелом. Изложенные положения могут стать основой законодательных природоохранных проектов.

Ключевые слова: природопользование, антропогенное влияние, принципы, комплексное управление береговой зоной (КУБЗ), береговая зона, северо-западная часть, Черное море, Украина.

Formulation of the problem. The problem of rational nature management and the protection of the coastal zone of the north-western part of the Black Sea, and the entire World Ocean attracted scientific interest in the middle of the twentieth century. Sea coasts have become the center of gravity for the population of the Earth, and as a result, the basis for the development of high socio-economic infrastructure. The intensive development of the coastal zone of the sea (CZS) and consumer economic activity have led to the development of destructive processes and degradation of natural systems [25,
34]. Solving this problem requires new scientifically based knowledge, new political approaches, public awareness, and most importantly, the development of integrated coastal zone management (ICZM). The concept of integrated coastal management appeared back in the 1980s of the last century, but was recognized in 1992 in Rio de Janeiro at the UN Conference (Agenda 21). The main goal of the concept is to preserve the natural resources of the coastal zone for the future generations, without upsetting the natural balance, but at the same time receiving economic benefits $[28,29]$. 
Solution to the problem of rational nature management at the seashore of the study area is possible only with qualified development and implementation of ICZM. In order to achieve harmony in the natural-anthropogenic system, «coastal zone of the sea man», close interaction of the scientific and legislative spheres is necessary (Fig. 4). Scientific information should comprehensively take into account physiographic and socio-economic processes, as well as the laws of their development that determine the current state and dynamics of changes in natural systems during their operation. In the study of sea coasts, the natural state of all its constituent elements, changes in the hydrometeorological regime, the many-year rise in the level of the oceans, the state of the coastal waters of the sea, just to mentioned a few. The information obtained can be used to address topical issues and develop a constructivegeographical framework for environmental management in the conditions of transcendental anthropogenic impact.

Analysis of recent research and publications. Nowadays, the issue of anthropogenic influence on the environment as a whole, and on the coastal zone in particular, is so relevant that many scientists are studying this problem. The first studies on the shores of the north-western part of the Black Sea were focused on the study of morphodynamic processes with the aim of building shore, port, hydrotechnical, recreational and other types of structures. Most publications on this topic belong to such famous Soviet geomorphologists and coastal scientists as: V. P. Zenkovich [15, 16], O. K. Leontyev [19], V. I. Lymarev [20], Yu. V. Artyukhin [3], N. A. Aybulatov [1], G. N. Aksent'ev [2], Yu. D. Shuisky [22-27], G. V. Vykhovanets [5, 25], and others.

Modern studies [5-6, 10-14, 17-18, 26-27 etc.] of the coastal zone in the Black Sea region are aimed at studying various risks on the sea coasts of natural and anthropogenic origin; on the development of scientific recommendations and principles; the introduction of ICZM in Ukraine; the improvement of the current legislative base of the state for the protection and renewal of natural resources. But unfortunately, such research in most cases is carried out at the initiative of altruistic scientists from different institutions, rather than the current legislative environmental authority of management.

Among the latest foreign publications worth highlighting are the findings of [28-38]. They are aimed at studying different types of socio-economic influence on the coastal zone of the World Ocean and its various parts; to search for ways of rational nature management and conservation of natural resources; to solve problems between the scientific and legislative spheres and to develop strategies for effective integrated coastal zone management (ICZM).

Identification of previously unsolved parts of a common problem. Despite the significant number of publications related to the research topic, the information requires a detailed synthesis for the development and improvement of the structural and geographical foundations of environmental management in the coastal zone of the north-western part of the Black Sea. The materials of the work are of significant structural and geographical importance in the implementation of ICZM, for the development of legislative projects and regulatory documents for the optimal use of the natural resources of the Black Sea coast, as well as in the planning and spatial organization of the coastal zone.

The purpose of the study is to analyze the current state of the coastal zone of the north-western part of the Black Sea, under conditions of uncontrolled anthropogenic influence, as well as the current management system of the coastal zone of the sea, to develop and to improve the structural and geographical foundations of rational environmental management.

Providing basic research materials. Ukraine is a maritime state washed by the Black and Azov Seas. The coastal zone of the north-western part of the Black Sea, according to hydrographic zoning [8], is the area of the first survey, the site, stretching from the Danube Delta to the Bakal Spit in Karkinitsky Bay. According to the developed regionalization of V. P. Zenkovich [16] and improved by his student Yu. D. Shuisky [23], three coastal regions are distinguished in the passages of this territory: Danube, North-Western and DnieperKarkinitskaya (Fig. 1).

The seacoast of this region is actively used in the socio-economic, transport, industrial, agricultural, recreational and other spheres of economic activity. CZS is under increasing pressure mainly due to population growth, urbanization, progressive development of infrastructure in combination with uncoordinated industrial, transport, recreational, coastal, fishing, agricultural and other activities [26]. Since this is important for the national economy, competition for its resources is growing, threatening to destroy the functional integrity of the natural system.

Unqualified intervention in CZS leads to destructive processes and degradation of natural systems. As a result, soil erosion, abrasion-landslide and landslide processes (Fig. 2), coastal waters, reduction of renewable resources, erosion of beaches and coasts (Fig. 3), destruction of the natural unique relief, loss of wetlands and loss of biodiversity, etc. $[25,26]$. 


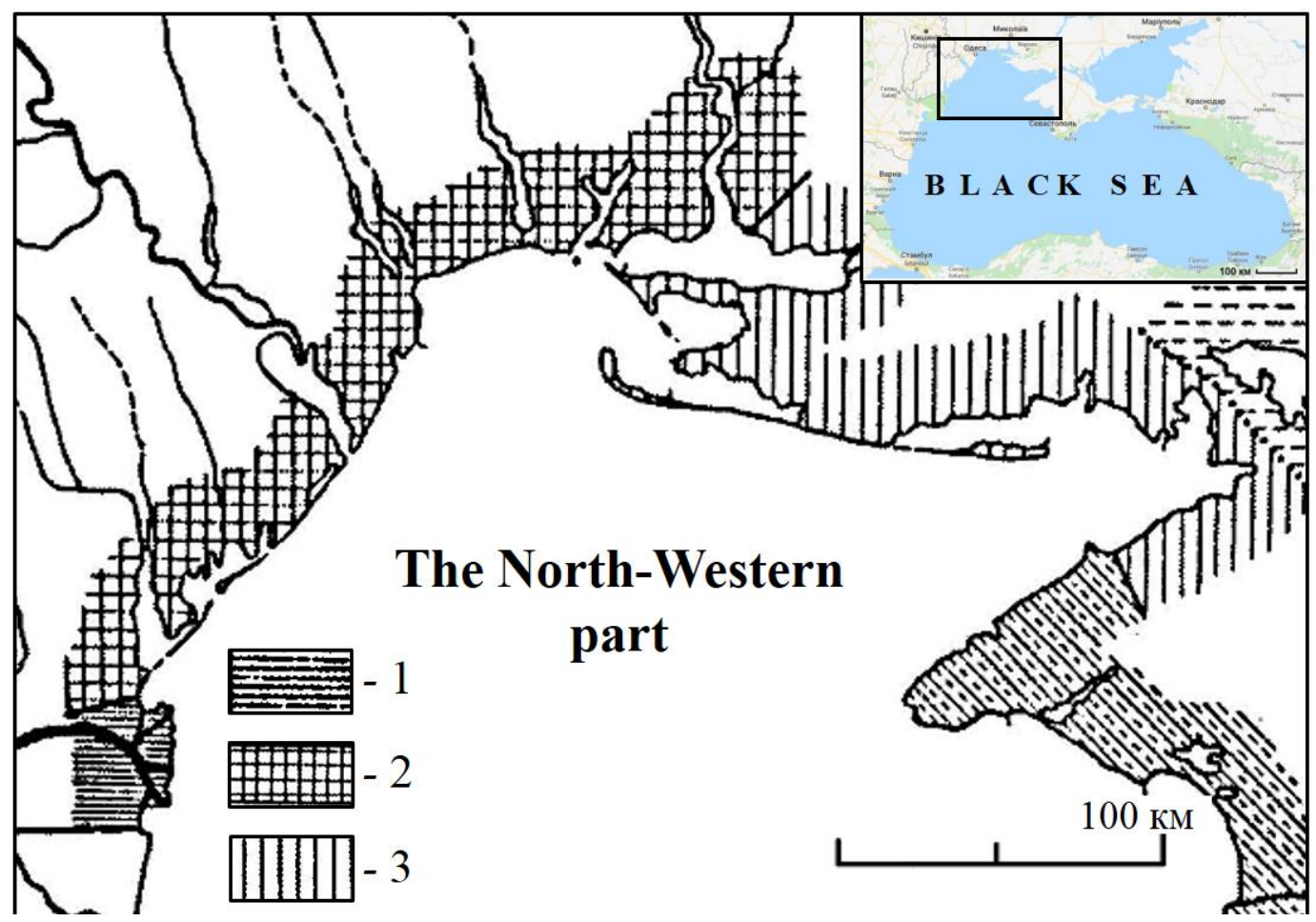

Fig. 1. The north-western part of the Black Sea within which the coastal areas are distinguished: 1 - Danube; 2 - North-Western; 3 - Dnieper-Karkinitskaya [16, 23]

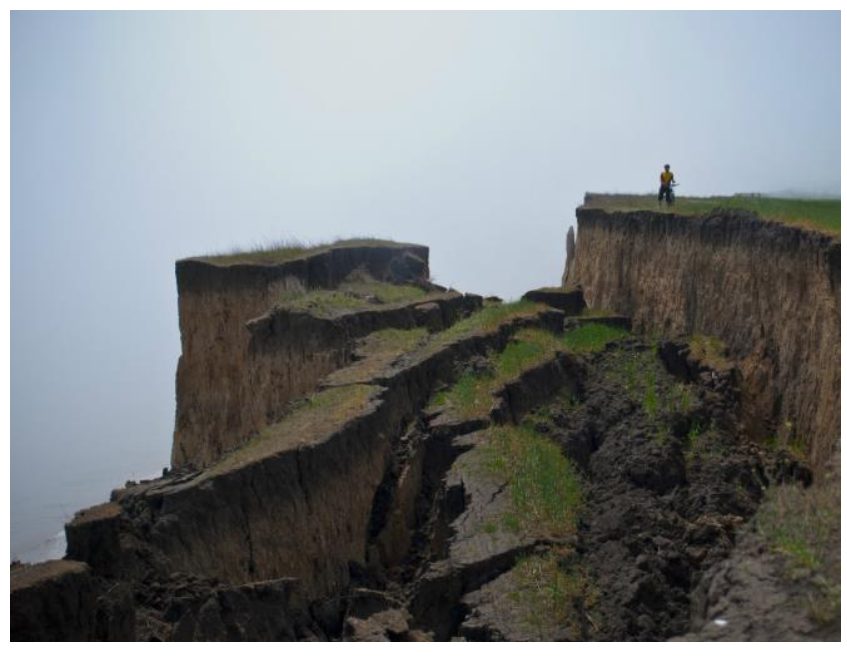

Fig. 2. Landslide in southwest Odessa, village Sanzheika

One of the reasons for the chaotic development of the coastal zone of the north-western part of the Black Sea is the fact that the interests of all legitimate users have not yet been recognized. Various administrations and enterprises pursue their «narrow» interests without a «big» connection with each other and do not discuss their plans for the future. However, to protect and preserve the coast, we need to do long-term integrated planning and recognize the legitimate interests of all users.

To solve this problem, most coastal countries in the world use integrated coastal zone management

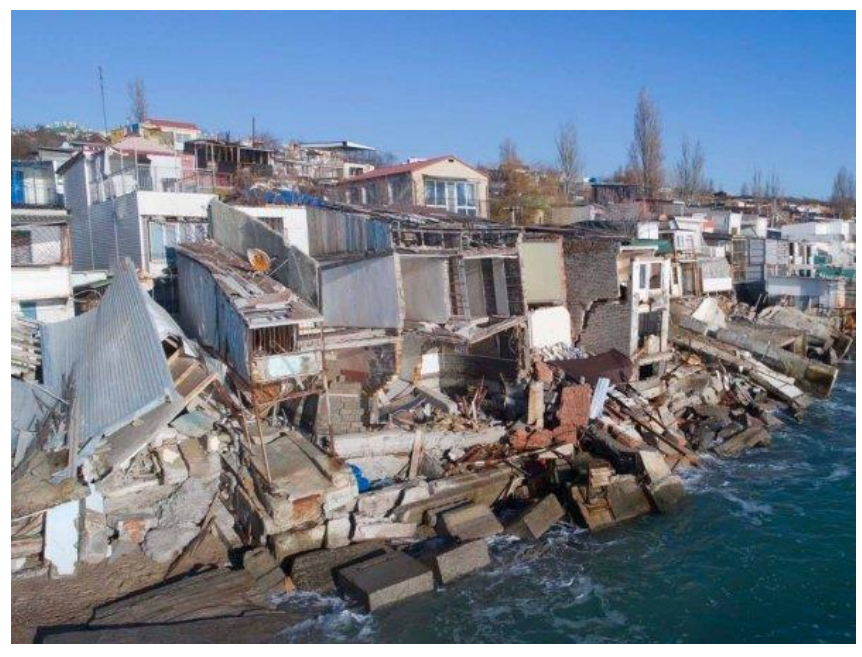

Fig. 3. The coast washout on the outskirts of Chernomorsk

(KUBZ). This concept implies a compromise and compliance with strict physiographic standards when making any interventions in the coastal zone. For example, the construction of an industrial complex or a port on the coast will be incompatible with the development of tourism, and may also destroy some particularly valuable natural systems. Effective implementation of the rules and environmental impact assessment are the tools for implementing KUBZ, which is a method for considering all the possible consequences associated with a given project or policy [28-38]. 
During the years of her independence, Ukraine also has attempts to introduce the ICZM of the Black and Azov Seas, but judging from the current state of the sea coasts, these were just attempts. The biggest catastrophes and financial losses occurred through the lack of awareness of citizens about the risks that CZS hides (Fig. 2, 3), as well as through the gap between scientific and legislative (political) areas of activity. Thus, there is an urgent need to apply integrated management of the Black Sea coast.

The objectives of the Black Sea coastal oil and sea sector are the main types of actions in all socioeconomic areas on which effective management depends:

$\checkmark$ To promote through rational planning of coastal sustainable development, by ensuring that the environment is taken into account in harmony with economic, social and cultural development;

$\checkmark$ To preserve the nature of the coastal zone for present and future generations;

$\checkmark$ To ensure sustainable use of natural resources, especially water;

$\checkmark$ To ensure the preservation of the integrity of the coast, ecosystems, coastal landforms;

$\checkmark$ To prevent and / or reduce the effects of natural disasters and, in particular, climate change, which may be caused by natural or human activities;

$\checkmark$ To harmonize and strengthen the environmental legislation of Ukraine and improve its implementation, as well as to ensure compliance with all prescribed norms;

$\checkmark$ To achieve coherence between public and private initiatives, as well as between all decisions of state bodies at the national, regional and local levels that affect the environmental management of the coastal zone;

$\checkmark$ To create effective management and decision-making mechanisms for the sustainable development of the Black Sea coastal zone [33].

BZM management should cover the full cycle of collecting scientific geographic information, planning, decision-making, management and monitoring of implementation. The ICZM should use the informed participation and cooperation of all interested parties to assess the socio-economic goals in the coastal zone and take certain measures. ICZM should strive for a long-term perspective to balance the interaction of scientific, economic, social, cultural, recreational and other spheres of activity of the population within the legislative norms $[32,37]$.

The long-term success of ICZM depends on influence of those groups' support and individuals whose interests will be most affected by the implementation of the program. The participation of all major ICZM stakeholders, including the general public is necessary for the participation of all stake- holders in the processes of program development and implementation [36].

In order to avoid the threat of the depletion of natural resources and disruption of the physicalgeographical balance, it is necessary to develop scientific principles of rational nature management, a system of measures aimed at protecting, rational use and restoring natural resources, as well as maintaining natural balance. It is very important to organize the protection not only of individual components of the BZM, but also the preservation and possible recovery of the entire coast as a whole, the protective functions of which have significantly decreased due to intensive economic activity [23].

When implementing the ICZM in the northwestern part of the Black Sea, the legislature can be guided by the following principles $[9,13,27,29$, 31, 33]:

Principle 1. The coastal zone is a unique system of natural resources, it requires special approaches to management and planning.

Principle 2. The use of an integrated approach to management and planning of the coastal zone in the interaction of land and sea.

Principle 3. Adaptive management during the ICZM process, which will facilitate adjustments as problems and knowledge evolve. This implies the need for a reliable scientific basis for the evolution of the coastal zone.

Principle 4. The main task in the management of natural resources of the coastal zone is to preserve the total public and private material resources.

Principle 5. Development of land use strategies, plans and programs covering urbanization and various types of socio-economic activities of mankind, as well as other policy actions necessary for a successful ICZM.

Principle 6. Support and participation of relevant administrative bodies at the national, regional and local levels, between which relevant links should be established or maintained in order to improve the coordination of the various existing policies.

Principle 7. The preservation of the sustainable use of natural resources is one of the main objectives of coastal zone management.

Principle 8 . Preliminary assessments should be conducted taking into account the risks of natural and anthropogenic origin in order to prevent and reduce their negative impact on the coastal zone.

Principle 9. An approach to environmental impact assessment is important for the effective management of coastal areas.

Principle 10. The organization of environmental systems in the coastal zone, which play the role of a kind of frame and allow you to preserve the most valuable natural complexes in their natural 
state.

Despite the wide range of scientific information in the coastal areas, unfortunately, there is no connection between science and politics. Thus, there are problems that prevent bridging the gap between the scientific and legislative spheres: 1) unsatisfactory participation of scientists in the management of coastal zone; 2) lack of reliable information and data for management planning initiatives; 3 ) difficulties associated with the communication of scientific findings and their applicability for decision-making.
Despite some interest in the legislative bodies to scientific and technical approach of solving problems of coastal areas, the integration of results into coastal zone management plans is not guaranteed since decisions are often made with a downward approach and without the participation of scientists from different organizations. For effective use of the Black Sea ICZM in Ukraine, taking into account anthropogenic influence, there must be a coordinated relationship between the scientific and legislative sphere (Fig. 4).

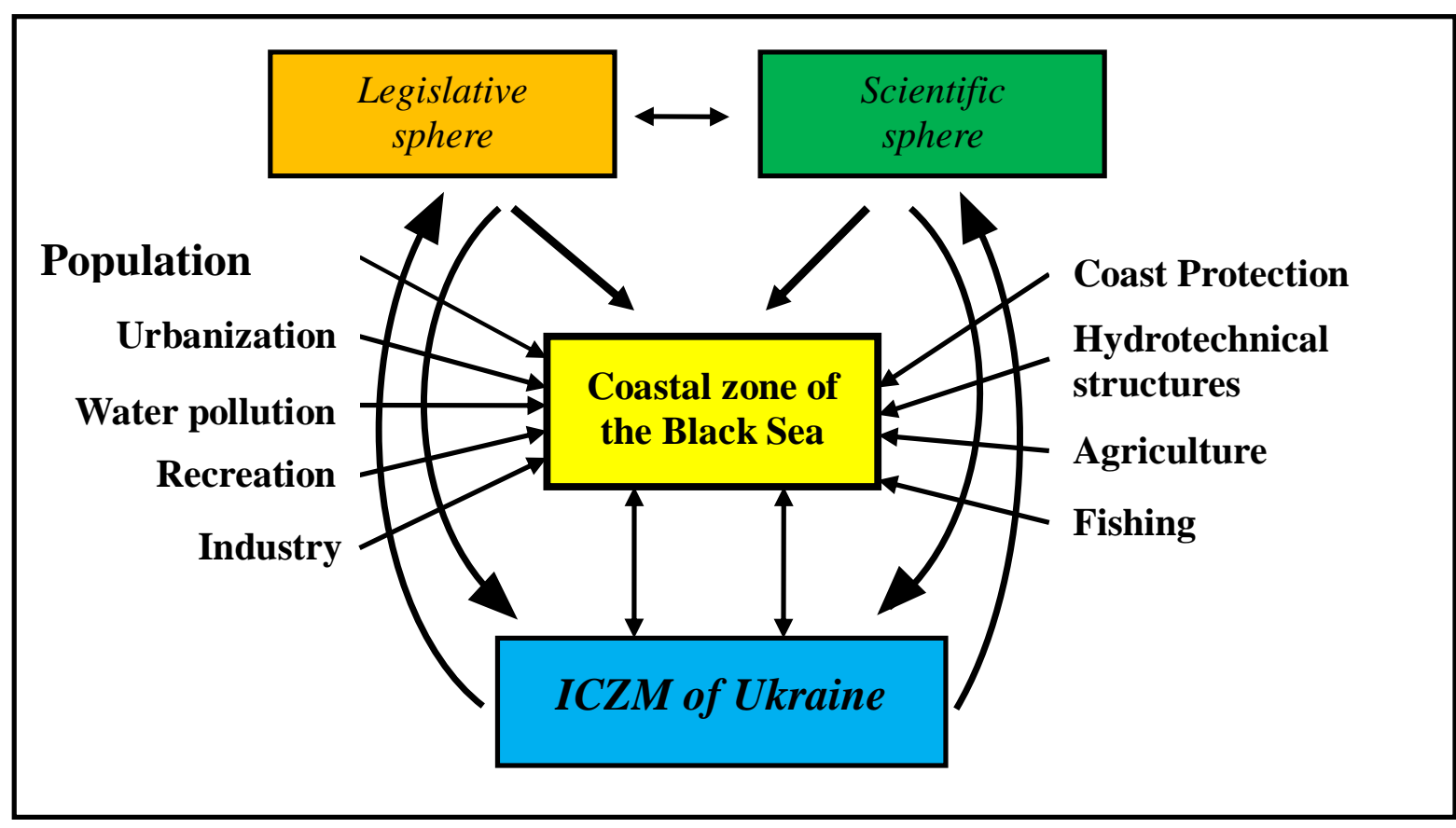

Fig. 4. Optimized scheme of integrated coastal zone management in the north-western part of the Black Sea [29]

It should be noted that the preservation of the natural resources and biodiversity of the coastline is more often constrained by political uncertainty and bureaucratic inertia than by lack of scientific information. This situation can only improve when the government begins to realize the importance of the resources in the coastal zone of the Black Sea.

Conclusions. The current state of the coastal zone of the Black Sea within Ukraine is under strong anthropogenic pressure. Vigorous economic activity (urbanization, recreation, agriculture, industry, fishing, construction of infrastructure, shore protection, hydrotechnical and other types of facilities) and, as a result, chaotic bank management have led to the development of destructive processes and degradation of the coastal zone of the Black Sea.

The seaboard of the north-western part of the Black Sea is one of the most important unique natural resources requiring the use of integrated coastal zone management (ICZM). This approach should provide a basis for the implementation of measures that are necessary to preserve the most important coastal natural systems for the present and the future generations.

It is necessary to establish a system of relations between the scientific and legislative sphere at ICZM. Any distribution rights to use coastal resources should be based on a scientific nature study with the assistance of all levels of government.

When developing projects for planning and carrying out of any kind of actions in the coastal zone of the Black Sea, one should take into account the historically established structure of the relationship between physiographic elements (coast, submerged slope, aeolian ridges, hydrometeorological conditions, vegetation, condition of coastal waters), including the processes and mechanisms of development of this natural system.

Developed and improved structural and geographical foundations of environmental management are universal and are important for harmonizing the relationship between humanity and nature, 
by reducing anthropogenic pressures not only within the coastal zone of the north-western part of the Black Sea, but also in the Black Sea countries and the World Ocean as a whole. These provisions can be the basis of legislative environmental projects.

\section{References}

1. Айбулатов Н. А. Динамика твердого вещества в шельфовой зоне / Н. А. Айбулатов. - Ленинград: Гидрометиздат, 1990. - 272 с.

2. Аксентьев Г. Н. Динамика рельефа подводного склона северо-западных берегов Черного моря / Г. Н. Аксентьев // Океанология. - 1970. - Т. 10. - № 3. - С. 448-456.

3. Артюхин Ю. В. Антропогенный фактор в развитии береговой зоны моря / Ю. В. Артюхин. - Ростов-наДону: Изд-во Ростовского университета. - 1989. - 144 с.

4. Веденин Ю. А. Динамичность среды и ресурсов в рекреационной деятельности / Ю. А. Веденин // Рекреаиионные ресурсы и методы их изучения. - Москва: Изд-во ГО СССР. - 1981. - С. 4-14.

5. Вихованеи Г. В. Влияние антропогенного фактора на современное состояние аккумулятивных форм рельефа северо-западной части Черного моря / Г. В. Выхованеи, Д. О. Панкратенкова // Вісник Одеського національного університету. Серія: Географічні та геологічні науки. - 2018. - T. 23. - Вип. 1. - С. 11-32.

6. Воровка В. П. Особливості управління природокористуванням у прибережсій смузі Азовського моря / В. П. Воровка // Вісник Харківського національного університету імені В. Н. Каразіна. Серія «Геологія. Географія. Екологія». - 2017. - Випуск 47. - С. 77-84.

7. Геоэкологические подходы к проектированию природно-технических систем / отв. ред. Т. Д. Александрова, В. С. Преображенский, П. Г. Шищенко. - М.: Ин-т географии АН СССР, 1985. - 236 с.

8. Гидрометеорология и гидрохимия морей СССР. Том IV. Черное море. Вып. 1. Гидрометеорологические условия / Под ред. А. И. Симонова, Е. Н. Альтмана. - СПб: Гидрометеоиздат, 1991. - 430 с.

9. Гродзинський М. Д. Заповідна справа в Украӥні: Навчальний посібник / за заг. редакиією М. Д. Гродзинського, М. П. Стеценка. - К.: Географіка, 2003. - 306 с.

10. Громова Е. Н. Комплексное антикризисное управление прибрежными зонами / Е. Н. Громова, В. И. Золотов, С. Г. Шунтова // Природні та природно-техногенні ризики берегової зони морів: Матеріали міжнародної конферениії (7-11 вересня 2008 р.). - Одеса: ІПРЕЕД НАН Украӥни. - 2008. - С. 130-131.

11. Демьяненко С. Г. Проекты берегозащиты в контексте формирования рынка экологических услуг / С. Г. Демьяненко, В. И. Золотов // Економічні інновачії. - 2011. - Вип. 58. - C. 95-105.

12. Демьяненко С. Г. Проблемы планирования развития морской береговой зоны / С. Г. Демьяненко, В. И. Золотов // Економіка: реалії часу. Науковий журнал. Серія: Сучасні проблели регіонального розвитку, 2012. №1(2). - C. 107-113.

13. Загальнодержавна програма охорони та відтворення довкілля Азовського $і$ Чорного морів: Затверджена Законом Украӥни від 22 березня 2001 р. № 2333-III // Відомості Верховної Ради. - 2001. - № 28.

14. Закономірності сучасного розвитку берегової зони морів Украӥни в умовах підвищеного антропогенного тиску і сучасних змін клімату: звіт про НДР (заключний) / кер. Ю. Д. Шуйський; викон.: Одеський державний університет імені I. І. Мечникова. - Одеса, 1999. - 87 с. - № ДР 0198V002242. - Інв. № 74735479.

15. Зенкович В. П. Берега Черного и Азовского морей / В. П. Зенкович. - М.: Географиз., 1958. - 374 с.

16. Зенкович В. П. Морфология и динамика советских берегов Черного моря: Том ІІ / В. П. Зенкович. - Москва: Изд-во АН СССР, 1960. - 216 с.

17. Зеркаль М. В. Конструктивно-географічні принципи територіальної організації берегових зон у населених пунктах / М. В. Зеркаль // Людина та довкілля. Проблеми неоекологіï. - 2013. - № 1-2. - С. 56-60.

18. Комплексное управление прибрежной зоной: от теории к практике. Центр региональных исследований. Одесса: Овидиополь, 2008. - 8 c. - Режим доступа: http://www.britishcouncil.org/uk/ukraine-sciencesepsprojects-2006.htm

19. Леонтьев О. К. Геоморфология морских берегов / О. К. Леонтьев, Л. Г. Никифоров, Г. А. Сафьянов. - М.: Изд-во Моск. ун-та, 1975. - 336 с.

20. Лымарев В. И. Береговое природопользование: вопросы методологии, теории, практики. Монография / В. И. Лымарев. - СПб.: РГГМУ, 2000. - 168 с.

21. Студенніков I. В. Інтегроване управління приморською зоною: базові поняття, принципи $і$ значення для сталого розвитку Украӥни / I. В. Студенніков, О. А. Дьяков // Стратегічна панорама. - 2005. - № 3. - С. $1-9$.

22. Шуйський Ю. Д. Напрямки захисту $і$ збережня природних ресурсів морських берегів у контексті потреб туризму / Ю. Д. Шуйський // Проблемы комплексного освоения и иелевого использования АзовоЧерноморского побережья Украиньл. - Одесса: Астропринт. - 1998. - C. 17-19.

23. Шуйський Ю. Д. Довжина берегів Чорного та Азовського морів у межах Украӥни / Ю. Д. Шуйский // Український Географічний журнал. - 2001. - № 1. - С. 33 - 36.

24. Шуйский Ю. Д. Основы стратегии строительства в береговой зоне Черного и Азовского морей / Ю. Д. Шуйский // Исследования береговой зоны моря. - Киев: Карбон Лтд. - 2001. - С. 8-24.

25. Шуйский Ю. Д. Экзогенные процессы развития аккумулятивных берегов в северо-западной части Черного моря / Ю. Д. Шуйский, Г. В. Выхованеи. - Москва: Недра, 1989. - 198 с. 
26. Шуйский Ю. Д. Краткая оченка влияния антропогенного фактора на береговую зону Черного моря / Ю. Д. Шуйский, Д. О. Панкратенкова // Арктические берега: путь к устойчивости: Материаль Конференции. Мурманск: МАГУ, 2018. - С. 277-280.

27. Шуйский Ю. Д. История развития и методология береговедения: монография / Ю. Д. Шуйский. - Одесса : Aстропринт, 2018. - 448 c.

28. Breen, B. Hynes, S. (2014). Shortcomings in the European principles of Integrated Coastal Zone Management (ICZM): Assessing the implications for locally orientated coastal management using Biome Portfolio Analysis (BPA) / B. Breen, S. Hynes // Marine Policy. - 2014. - P. 406-418.

29. Coastal Zone Management Authority and Institute (CZMAI). Belize Integrated Coastal Zone Management Plan: [Electronic resource]. - Access mode: https://www.coastalzonebelize.org/

30. Coastal zones: achieving sustainable management. Science for Environment Policy. - InTech, 2014. doi: $10.2779 / 53698$.

31. Clark, R. J. Integrated management of coastal zones. / R. J. Clark // Research Associate National Park Service Program Rosenstiel School of Marine Sciences University of Miami, Florida, USA. - 1994. - 327 p.

32. Harvey, N., Caton, B. Coastal Management in Australia / N. Harvey, B. Caton. - 2010. - 361 p.

33. Ibrahim H. The Role of SEA in Delivering High Level Environmental Policy Objectives in Coastal Zone Management in Egypt / H. Ibrahim, I. Hegazy // Coast Zone Management. - InTech, 2015. doi: 10.4172/24733350.1000405

34. Guideline on Integrated Coastal Zone Management: [Electronic resource]. - Access mode : http://www.blackseacommission.org/Downloads/Black_Sea_ICZM_Guideline/Black_Sea_ICZM_Guideline.pdf

35. Obraczka, M., Beyeler, M., Magrini, A., Legey, L. F. (2017). Analysis of Coastal Environmental Management Practices in Subregions of California and Brazil / M. Obraczka, M. Beyeler, A. Magrini, L. F. Legey // Journal of Coastal Research. - InTech, 2017. doi: 10.2112/JCOASTRES-D-15-00239.1.

36. Swamy, D. A. Coastal Zone Environmental Management in Udupi District, Karnataka State, India / D. A. Swamy, B. E. Basavarajappa, E. T. Puttaiah // International Journal of Engineering and Science. -2012. - Vol. 1, Is. 3. - P. $8-11$.

37. Wang, X. H. Integrated coastal zone management research in Australia and China /X. H. Wang, S. G. Pearson, R. J. Morrison, P. Shi, X. Xu, G. Xue, D. Liu // Labour and Management in Development Journal. - 2011. - Vol.11. P. $1-17$.

38. Xuea, X. Cumulative environmental impacts and integrated coastal management: the case of Xiamen, China / X. Хиеа, H. Honga, A. T. Charlesb // Journal of Environmental Management. - InTech, 2004. doi: 10.1016/j.jenvman.2004.03.006.

UDC 551.35+911.3:504.052

\section{Daria Pankratenkova,}

Senior Lecturer, Department of Physical Geography and Environmental Sciences, I. I. Mechnikov Odessa National University, 2 Shampanskiy Per, Odessa, 65058, Ukraine, e-mail: dashap15041989@gmail.com, https://orcid.org/0000-0002-9888-7281

\section{CONSTRUCTIVE-GEOGRAPHIC FOUNDATIONS OF NATURE MANAGEMENT ON THE NORTH-WESTERN COAST OF THE BLACK SEA}

The aim of the research is to analyze the problem of anthropogenic influence on the sea coasts, to develop and improve the constructive-geographical foundations of rational nature management for the conservation and possible renewal of natural resources on the north-west coast of the Black Sea.

Methods. The main methods used in the preparation process and writing of the article are systematization methods, retrospective, analytical, comparative geographical and historical.

Scientific novelty of the article. The fact that the coastal zone of the Black Sea coast is experiencing uncontrolled anthropogenic impacts; this research has improved and developed constructive-geographical foundations for their rational management.

Practical value. Developed scientific recommendations are universal. They are very important for the implementation of integrated management of the coastal zone in the country, the optimization of nature management and the preservation of the natural systems on the north-west coast of the Black Sea, in particular, and the entire World Ocean, as a whole.

Research results. Intensive development of the coast and consumer economic activity over the past decades has led to the degradation of natural systems. Rational use of natural resources of the coastal zone of the sea assumed the development of foundations that comprehensively take into account the physicalgeographical and socio-economic processes, as well as the laws of their development that determine the current state and dynamics of changes in natural systems during their operation. On the basis of a detailed study 
of domestic and foreign publications related to this topic, the activities of integrated coastal zone management (ICZM) in different countries of the world were analyzed. The foundations and principles for introducing ICZM in Ukraine are highlighted. It has been established that for the development of any projects in the coastal zone of the sea, it is necessary to have a scientific natural rationale from scientists obtained in the process of detailed research. These provisions can be the scientific basis of the relevant legislative framework for the optimization of nature management and spatial planning on the north-west coast of the Black Sea.

Well-developed and improved scientific provisions are suitable for correcting the current situation in the direction of higher efficiency on coastal control. These constructive-geographic foundations can become the basis and the main algorithm for practical implementation of environmental legislation in Ukraine.

Keywords: nature management, principles, anthropogenic influence, integrated coastal zone management (ICZM), coastal zone, north-west, Black Sea, Ukraine.

\section{References}

1. Aybulatov, N. A. (1990). Dynamics of solid matter in the shelf zone. Leningrad, 272 [in Russian].

2. Aksent'ev, G. N. (1970). Dynamics of the relief of the underwater slope of the north-western shores of the Black Sea, Oceanology, V. 10, № 3, 448-456 [in Russian].

3. Artyukhin, Yu.V. (1989). Anthropogenic factor in the development of the coastal zone of the sea. Rostov-on-Don, 144 [in Russian].

4. Vedenin, Yu. A. (1981). Dynamism of the environment and resources in recreational activities. Recreational resources and methods for their study, 4-14 [in Russian].

5. Vihovanets, G. V., Pankratenkova, D. O. (2018). The influence of the anthropogenic factor on the current state of the accumulative relief forms of the north-western part of the Black Sea. Odessa National University. Series: Geographical and geological sciences, 11-32 [in Russian].

6. Vorovka, V. P. (2017). Peculiarities of nature management in the coastal zone of the Azov Sea. Visnyk of V. N. Karazin Kharkiv National University. Series: Geology. Geography. Ecology, 77-84 [in Ukrainian].

7. Alexandrova, T. D., Preobrazhensky, V. S., Shishchenko, P. G. (1985). Geoecological approaches to the design of natural-technical systems. Moscow, 236 [in Russian].

8. Simonov, A. I., Altman, E. N. (1991). Hydrometeorology and hydrochemistry of the seas of the USSR. Volume IV. Black Sea. Issue 1. Hydrometeorological conditions. SPb: Gidrometeoizdat, 430 [in Russian].

9. Grodzinskii, M. D., Stetsenko, M. P. (2003). Protected Case in Ukraine: Textbook. K.: Geography, 306 [in Ukrainian].

10. Gromova, E. N., Zolotov, V. I., Shuntova, S. G. (2008). Integrated anti-crisis management of coastal zones / E. N. Gromova. Natural and natural-man-made risks of the coastal zone of the sea: Materials of the international conference, 130-131 [in Russian].

11. Demyanenko, S. G., Zolotov, V. I. (2011). Coastal protection projects in the context of the formation of the market for environmental services. Economic Innovations, 95-105 [in Russian].

12. Demyanenko, S. G., Zolotov, V. I. (2012). Problems of planning the development of the marine coastal zone. Ekonomika: real hour. Science magazine. Series: Modern problems of regional development, 107-113 [in Russian].

13. National Program for the Protection and Restoration of the Environment Azov and Black Seas: Approved by the Law of Ukraine dated March 22, 2001 № 2333-III. (2001). Information from the Verkhovna Rada, № 28 [in Ukrainian].

14. Shuisky, Yu. D. (1999). Patterns of modern development of the coastal zone of the seas of Ukraine in conditions of increased anthropogenic pressure and modern climate change: GDR report (final). Executed: Odessa Mechnikov State University. № 0198V002242. Inv. № 747Z5479, 87 [in Ukrainian].

15. Zenkovich, V. P. (1958). Coasts of the Black and Azov Seas. Moscow, 374 [in Russian].

16. Zenkovich, V. P. (1960). Morphology and dynamics of the Soviet shores of the Black Sea: Volume II. Moscow: Publishing House of the Academy of Sciences of the USSR, 216 [in Russian].

17. Zerkal', M. V. (2003). Constructive-geographic principles of territorial organization of coastal areas of population points. Man and the environment. Problems of neoecology, № 1-2, 56-60 [in Russian].

18. Leontyev, O. K., Nikiforov, L. G., Safyanov, G. A. (1975). Geomorphology of the Sea Shores. Moscow: Publishing House of Moscow. University, 1975. 336 [in Russian].

19. Integrated coastal zone management: from theory to practice. Center for Regional Studies. (2008). Odessa: Ovidiopol, 8. Available at : http://www.britishcouncil.org/uk/ukraine-science-sepsprojects-2006.htm

20. Lymarev, V. I. (2000). Coastal environmental management: questions of methodology, theory, practice. Monograph. $S P b ., 168$ [in Russian].

21. Studunnikov, I. V., Dyakov, O. A. (1988). Integrated Coastal Zone Management: Basic Concepts, Principles and Importance for Sustainable Development of Ukraine. Strategic Panorama, № 3, 1-9 [in Russian].

22. Shuisky, Yu. D. (1998). Directions of protection and preservation of natural resources of the seas in the context of the needs of tourism. Problems of complex development and target use of the Azov-Black Sea coast of Ukraine, 1719 [in Russian]. 
23. Shuisky, Yu. D. (2001). The length of the shores of the Black and Azov Seas within Ukraineю Ukrainian Geographic Journal, № 1, 33 - 36 [in Ukrainian].

24. Shuisky, Yu. D. (2001). Basics of the construction strategy in the coastal zone of the Black and Azov seas. Studies of the coastal zone of the sea, 8-24 [in Russian].

25. Shuisky, Yu. D., Vykhovanets, G.V. (1989). Exogenous processes of development of accumulative coasts in the north-western part of the Black Sea. Moscow, 198 [in Russian].

26. Shuisky, Yu. D., Pankratenkova, D. O. (2018). Brief assessment of the influence of the anthropogenic factor on the coastal zone of the Black Sea. Arctic shores: the path to sustainability: Conference materials, 277-280 [in Russian].

27. Shuisky, Yu. D. (2018). History of development and methodology of coastal science. Odessa, 448 [in Russian].

28. Breen, B., Hynes, S. (2014). Shortcomings in the European principles of Integrated Coastal Zone Management (ICZM): Assessing the implications for locally orientated coastal management using Biome Portfolio Analysis (BPA). Marine Policy. 406-418

29. Coastal Zone Management Authority and Institute (CZMAI). 2016. Belize Integrated Coastal Zone Management Plan. Available at: https://www.coastalzonebelize.org/

30. Coastal zones: achieving sustainable management. (2014). Science for Environment Policy. 46,16. doi: $10.2779 / 53698$

31. Clark, R. J. (1994). Integrated management of coastal zones. Research Associate National Park Service Program Rosenstiel School of Marine Sciences University of Miami, Florida, USA. 327.

32. Harvey, N., Caton, B. (2010). Coastal Management in Australia. 361.

33. Ibrahim H., Hegazy I. (2015). The Role of SEA in Delivering High Level Environmental Policy Objectives in Coastal Zone Management in Egypt. Coast Zone Management. 18, 405. doi: 10.4172/2473-3350.1000405

34. Guideline on Integrated Coastal Zone Management. Available at: http://www.blacksea-commission.org/

35. Obraczka, M., Beyeler, M., Magrini, A., Legey, L. F. (2017). Analysis of Coastal Environmental Management Practices in Subregions of California and Brazil. Journal of Coastal Research. 33 (6), 1315-1332. doi: 10.2112/JCOASTRES-D-15-00239.1.

36. Swamy, D. A., Basavarajappa, B. E., Puttaiah, E. T. (2012). Coastal Zone Environmental Management in Udupi District, Karnataka State, India. International Journal of Engineering and Science. 1 (3), 8-11.

37. Wang, X. H., Pearson, S. G., Morrison, R. J., Shi, P., Xu, X., Xue, G., Liu, D. (2011). Integrated coastal zone management research in Australia and China. Labour and Management in Development Journal. 11, 1-17.

38. Xuea, X., Honga, H., Charlesb, A. T. (2004). Cumulative environmental impacts and integrated coastal management: the case of Xiamen, China. Journal of Environmental Management. 71, 271-283. doi: 10.1016/j.jenvman.2004.03.006. 